\title{
DOMINATION RIBAWI TRANSACTIONS IN THE ECONOMY
}

\author{
Dyarini $^{1}$ \\ ${ }^{\text {I} A f i l i a s i: ~ U n i v e r s i t a s ~ M u h a m m a d i y a h ~ J a k a r t a, ~ E c o n o m i c ~ a n d ~ B u s i n e s s ~ F a c u l t y . ~ E m a i l: ~}$ \\ rini_dyarini@yahoo.com
}

\begin{abstract}
Though the fight against usury command is a cornerstone of Islamic finance but the debate about the significance of the word "Riba" precisely still persistent. since the beginning of the advent of Islam, the majority of scholars has adopted a strict definition of usury, that all forms of interest can be said to be riba. but the debate continually held until now. some opinions reject these definitions and argued that Islam tolerate a reasonable interest rate. Therefore, this article will explain about riba and significance.
\end{abstract}

Keywords: Riba, Economic Transaction, Islamic Economic

\begin{abstract}
ABSTRAK. Perang terhadap riba adalah salah satu inti dari ajaran Islam, tetapi diskursus tentang signifikansi kata "Riba" masih terus bergulir. Sejak awal masa Islam, mayoritas Ulama telah mengadopsi secara jelas definisi riba, bahwa seluruh bentuk tambahan dapat dikatakan sebagai riba. Tetapi debat terus berlanjut hingga saat ini. Beberapa pendapat menolah defenisi ini dan beragumen bahwa Islam menolerir suatu tingkat suku bunga tertentu. Oleh karena itu, artikel ini akan menjelaskan tentang riba dan signifikansinya.
\end{abstract}

Keywords: Riba, Transaksi Ekonomi, Ekonomi Islam

\section{INTRODUCTION}

Usury was firstly prohibited in Arab region and after that in the regions where Islam rules. Therefore, the whole operation of the economic system that has Riba elements is forbidden. Therefore, the hallmark of Islamic economics or sharia business is anti-riba concept. This concept eliminates all kinds of riba in every transaction, either in real sector especially in financial sector. In facing economics in globalization era, it seems there is no limitbetween countriesanymore, the world is more transparent, the economic forces increasingly converge, they join in mergers, joint veture, holding company, or cooperation among countries to form a multinational company, which is the combined company among nations. If these activities are not guided by a certain ethic, they begin to eliminate the boundaries of good and bad, which is either permitted or not permitted, they began to blur the haram and halal. The business progress they earned was due in part to the relationship of debt and claim between them either the industrial employers, trade, agricultural and banking company or loan between individuals and other companies.

Thus, the domination of usury transactions in the economy has had an impact on the fluctuation of inflation rate and potential as a tool of human exploitation, leads to distribution unfairness, and brought to the truth 
marginalization. Riba is additional value obtained with no risk and not a gift or work compensation. Therefore, riba is possible on trade or financial transactions. Riba in trade incurred from the exchange of similar goods that do not meet the same criteria of quality, quantity, and the time of delivery, such as the case of sale and purchase of foreign currencies that are not made in cash. These kinds of transaction are forbidden in Islam because it contains gharar or uncertainty for both parties and have an impact on injustice.

The development of sharia financial institutions with its existing instruments raises optimism on the change of responds toward the existence of riba, although there are still many reasons that make the interest is less acceptable as riba such as there are many educational institutions tend to introduce interest as part of monetary instruments of the financial system in a country and the Muslim community is more familiar with the conventional systems.

\section{LITERATURE REVIEW}

\subsection{DEFINITION OF RIBA}

Riba according to its language means extra (az-Ziyadah), developing (annumuw), increasing (al-irtifa '), and enlarging (al-'ulu). In other words, riba is the extra, development, improvement, and enlargement of the principal loan received by the lender from the borrower in return for suspending or separated from most of the capital for a certain period of time. In this case, Muhammad ibn Abdullah ibn al-Arabi al-Maliki in the book Ahkam alQur'an said that extra which is included in riba is extra which is taken without 'iwad (balancer / replacement) which is justified by sharia. Likewise, Imam Sarakhi in the book Al-Mabsut mentioned that extra which is included in riba is riba which is required in the business transactions without iwad justified by sharia on such addition. While Badr ad-Dien al-Ayni in the book Umdatul Qari said that extra which is included in riba is extra or principal assets in the absence of real business transactions.

According to Sayyid Sabiq in the book Fikih Sunnah, what is meant by riba is extra to the capital either the extrat is a little or a lot. Likewise, according to Ibn Hajar 'Askalani, riba is the excess, either in the form of goods or money. Meanwhile, according to Allama Mahmud Al-Hasan Taunki, riba is an excess or addition; and if in a contract of goods exchange of more than one which is required as one same goods. There are some differences in the definition of riba among the scholars, but the difference is more influenced by interpretation of the experience of each of scholars on riba in the context of their life. So even if there are differences in defining it, but the substance of the definition is the same. In general, the Muslim economics affirm that riba is taking the extra to be paid, either in the buy-sell or loan transactions that is in contrary to the principles of Sharia. 


\subsection{TYPES OF RIBA}

In a broadly outline, riba is divided into two groups. Each is riba of debts and riba of sale and purchase. The first group is divided into riba qardh and riba jahiliyah. The second group, sale and purchase riba, is divided into riba Fadl and riba nasiah. The explanation of the above division is as follows:

1. Riba Qardh is a particular benefit or certain excess levels required to the debtors (muqtaridh).

2. Riba Jahiliyah is the debt paid more than its principal because the debters are unable to pay its debts at the time prescribed. Riba Jahiliyah is prohibited because of the principle of "kullu qardin Jarra Manfa ah fahuwa riba" (every loan that that takes interest is riba). In terms of delay of its delivery time, riba jahiliyah is classified as riba nasiah; in terms of similarity of objects that are exchanged it is classified as riba Fadl. Qurtuby exegesis explains: "In the Jahiliyah era the creditors, if the debt is due, will say to the debtors; "Pay of your debt now, or you delay the payment with the extra". Then the debtors must increase the amount of its loan obligations and the criditors are waiting the time of payment of such obligations in accordance with the new provisions".

3. Riba Fadl is also called riba buyu that is riba arising from the exchange of similar goods that does not meet the same quality criteria (mitslan bi mistlin), the same quality (sawa sawa's bi-in) and the same time of its delivery (Yadan bi yadin). This exchange contains gharar that is uncertainty of each value of goods exchanged for both parties. This lack of clarity can lead to unjust actions against one of the parties, the parties and other parties. For example, $1 \mathrm{~kg}$ of rice is sold by 1 and one fourth $\mathrm{kg}$. The excess of one-fourth is so-called the riba Fadl. This Sale and purchase only applies in almuqayadah (barter), namely goods is exchanged for goods and not to the value of money.

4. Riba Nasiah is also called riba duyun that is riba arising from debts that do not meet the criteria of profit that appear along with the risk (al-ghunmu bil ghurmi) and the business result that appears along with costs (al-kharaj bi Dhaman). This transaction contains liability exchange that burden only because of the passage of time. Riba nasia which is exchanged with other types of usury things. For example barter of similar types of goods, buy a kilogram of sugar, which will be paid one month to come. Or barter in goods which are not similar, such as buy one kilogram of flour and two kilograms of rice that will be paid two months to come. Excess of one item, a type or not, coupled with payment delays at certain times, including riba an-nasi'ah. 


\subsection{PRINCIPLES OF RIBA}

The principles for determining the existence of Riba in credit or barter transactions are taken from the Rasulullah saw's words, namely:

1. The exchange of goods of the same type and value, but different in amount, either in credit or cash, contains the riba elements. For example, there are riba elements in the exchange of one ounce of gold with a half-ounce of gold.

2. The exchange of goods of the same type and amount, but different in the value or price and is made in credit, containing riba elements. Such exchanges will be free of elements of riba when it is conducted from hand to hand in cash.

3. The exchange of the goods of the same value or the price but different in kinds and quantity, and is made in credit, containing riba elements. But if this exchange is conducted by way of hand to hand in cash, the exchange will be free of elements of riba. For example, if an ounce of gold has the same value of one ounce of silver. Then it is stated valid if the exchange is conducted from hand to hand in cash. In contrary, the transaction is declared illegal if done in credit because of the element of riba.

4. The exchange of goods of different types, value and quantity, eiher in credit or from hand to hand, freed from riba so it is allowed. For example, a salt and wheat, can be exchanged, either from hand to hand as well as a line of credit, according to the quantity agreed upon by both parties.

5. If the goods are the mixture that change its type and value, the exchange with different quantities either in credit or from hand to hand, free from the elements of riba so it is legitimated. For example, gold jewelry is exchanged with gold or wheat is exchanged with wheat flour.

In money-based economy, where the price of goods is determined by the standard of a country's currency, the exchange of goods with different quantityeither in credit or from hand to hand, both of them is free from riba, and therefore they are allowed. For example, one grade of other wheat is 15 $\mathrm{kg}$ per dollar. Both of these wheat grade can be exchanged for the same quantity without doubt of the existance of riba because the transaction was carried out under the provisions of wheat prices, not based on the type or severity.

\section{DISCUSSION}

\subsection{AYAHSES OF RIBA AND ITS COMMENTARY}

While the ayahs relating to riba and its interpretation, namely that in the Koran, it is found that the word riba is repeated eight times, contained in four 
Jurnal Ekonomi dan Perbankan Syariah

Vol. 5. No.1, April 2017: 5-18, ISSN (cet): 2355-1755 | ISSN (online): 2579-6437

$\mathbf{9}$

Surahs, al-Baqarah, Ali 'Imran, al-Nisa', and al-Rum. The first three surahs are "Madaniyah" (overturned after the Prophet migrated to Medina), while the Surah al-Rum is "Makiyyah" (overturned before his Hijrah). This means that first ayahs that speaks of riba is surah al-Rum ayahs 39 which states:

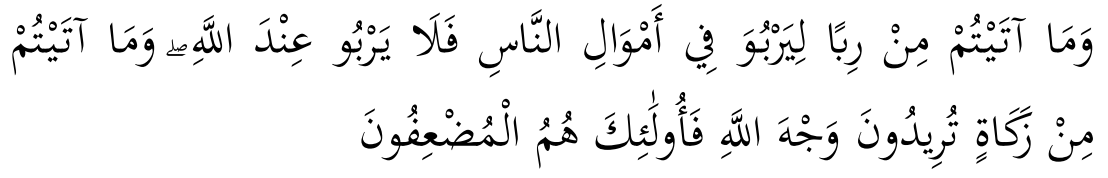

Which means:'That which ye give in riba in order that it may increase on (other) people's property hath no increase with Allah; but that which ye give in charity, seeking Allah's Countenance, hath increase manifold".

Subsequently, Al-Sayuthi, cited the narrations of Bukhari, Ahmad, Ibn Majah, Ibn Mardawaih, and Al-Bayhaqi, comment on that the last ayahs down to the Rasulullah saw. are ayahs in its threads there is a final explanation of riba, i.e. ayah 278-281 surat al-Baqarah, which reads:

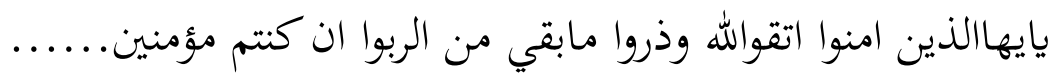

Which means:" O you who believe! Be afraid of Allah and give up what remains (due to you) from Riba (usury) (from now onward), if you are (really) believers........."

Subsequently Al-Zanjani, based on some narrations, among others from Ibn al-Nadim and the conclusions expressed by Al-Biqa'i and the orientalist Noldeke, argued that Surah Ali 'Imran first down from surah AlNisa'. If their conclusion is accepted, the meaning of ayah 130 of Surah Ali 'Imran which is strictly prohibit taking riba exponentially, is the second ayah received by the Prophet, while ayah 161 of Surah al-Nisa' contains criticism of Jews who eat riba.

While Surah Annissa ayah 161 is read:

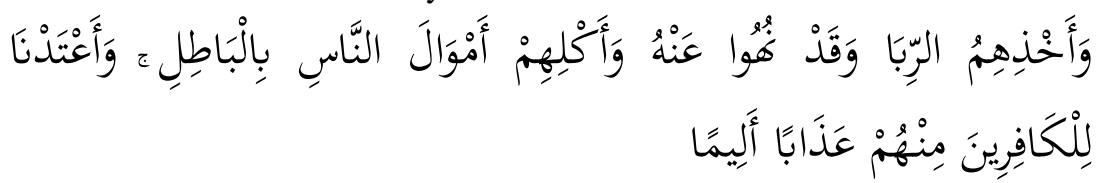

Which means:"And their taking of Riba (usury) though they were forbidden from taking it and their devouring of men's substance wrongfully (bribery, etc.). And We have prepared for the disbelievers among them a painful torment."

According to al-Maraghi and al-Shabuni, the stages of the Koran talks about Riba as same as stages talking on khamr (liquor), which in the first stage merely describing their negative elements in it (al-Rum, 30: 39), followed by a hint of its prohibition (Surah al-Nisa ', 4: 161). Subsequently in the third stage, explicitly, declared the prohibition of one of its forms (Surah Al 'Imran, 3: 130), and at the last stage, it is forbidden in total in its various forms (Surah al-Baqarah, 2: 278). 
In designating the demands on the above stages, both commentators did not put a narration that support it, while the scholars agree that it impossible to know the order of the descent of the ayahs without the basis of narration that is authentic, and that the fall of surah precedes another surah does not automatically make all the ayahs in the surahs that are stated preceding first down the entire ayahs in the surah stated down later. On the basis of these considerations, it tends to just set and discuss the first and last ayah concerning riba, then makes the second ayah is not clear position as the mid-downs stages.

This would not be a lot of influence in understanding the meaning or the essence of riba forbidden by al-Qur'an, because, as noted above, Surah alNisa ', 4: 161 is the criticism of the Jews who practice riba. Unlike the case of ayah 130 of Surah Ali Imran which uses redaction explicitly ban against the believers not to practice riba in adh'afan mudha'afah. This Ali 'Imran ayah, either made as the second stage and third stage of the ayahs, it is obviously preceded the fall of Surah al-Baqarah, 2: 278, and in the same time down after the fall of the ayah of Surah al-Rum, 30: 39.

On the other hand, al-Rum, 30: 39 which is the first ayah that speaks of riba, assessed by the scholars of Commentary not talking about riba which is forbidden. al-Qurtubi and Ibn al-'Arab called riba discussed by such ayah as proper riba. While Ibn Kathir named permissible riba. They all refer to the Prophet's companions, especially Ibn 'Abbas and several successors who interprets riba in these ayahs as "gifts" made by people who expect something in excess return. The difference in the meaning of the word riba in ayah of Surah al-Rum above with the word Riba in other ayah, al-Zarkasyi in al-Burhan interpret teh cause of the difference of writing in the mush-haf, that is the word riba in Surah al-Rum is written without using the letter waw, and in other surahs use it. From here, Rashid Rida made it as the starting point of her description of riba which is forbidden in the Qur'an begun with the surah Ali 'Imran 131.

If so, a brief discussion about the riba forbidden in al-Qur'an can be put forward by analyzing the content of ayahs of Surah Al 'Imran, 3: 130 and Surah al-Baqarah, 2: 278, or more specifically, by understand the key words of the ayahs, namely (a) adh'afan mudha'afah; (b) baqiya ma mi al-usury; and (c) lakum ru'usu amwalikum fa, la tazhlimuna wa la tuzhlamun. By understanding these key words, it is expected to find answers about the riba forbidden in al-Qur'an. In other words, "what is something that makes the advantages are forbidden".

While the views of scholars about the meaning of Adh'âfan Mudhâ'afah that in terms of language, the word adh'af is plural from the word dha'if that is defined as "something with something else in common with (double)". So adh'afan mudha'afah is multiplication. Al-Tabari in his commentary about the narrations that can lead us to the definition of adh'afan mudha'afah or riba applicable during the descent of the Koran. The narrations include: 
From Ibn Zayd that his father pointed out that "riba in jahiliyah era was in the multiplication and age (animals). Someone who owe, when the due of payment come, encountered by the debtor and said to him," Pay off or you add it for me. "And when creditors have something (for payment), he paid off his debts, and if he did not make the debt (when an animal) an animal that was older (than ever borrowed). if what he borrows is one year old and has entered the second year (binti makhadh), it is made as payment then binti labun who two years old and has entered his third year. Then it became hiqqah (which is entering its fourth year), and so on into jaza'ah (the fifth year), and so on. Meanwhile, if what he borrowed is material (money), the debtor came to charge, if he is not able, he is willing to double it so that it becomes a 100, in the following year become 200 and if it is not yet paid it will become 400. Similarly, every year until he is able to pay.

Mujahid narrated that riba which is forbidden by Allah SWT is what was practiced in Jahiliyah Era, that is a person has receivables to others, then the borrower said to him or her "for you (extra) as a return for payment delays", then the payment was delayed to him or her. Meanwhile, Qatada stated that riba in Jahiliyah Era was the person's sales to another (with payment) to a certain time. When it was due, while the concerned did not have the ability to pay, the amount of debt was added and the payment period was deferred.

The narrations above and another matching with the same are stated by the scholars of commentary when discussing ayah 130 of Surah Ali 'Imran. There are matters that need to be underlined concerning the narrations that has been put forward. First, the addition of the amount of receivable described by three narrations is not conducted at the time of the transaction, but put forward by the creditors (2nd commentary) or debtors (3rd commentary) at the time of due payment period. In this case, Ahmad Mustafa Al-Maraghi (1883-1951) commented in his commentary:

"Riba in Jahiliyah Era is riba, which is named with the one currently called as riba fahisy (the cruel or excessive riba), the multiple benefits. Addition which is fahisy (exaggerated) occurred after the repayment period, and none of the additions (which were cruel or excessive) in the first transaction, such as giving him or her 100 with the (returning) of 110 or more or less (of such amount). Apparently they felt sufficiency with the little advantage (few additions to the first transaction). But, when the payment period has arrived and not yet repaid, while the borrower at the time was in their grasp, they were forced to hold a multiplication as the exchange of delays. And it is called as riba al-nasi'ah (riba due to delays). Ibn 'Abbas argued that the nash of Qur'an refers to the known riba al-nasi'ah (at the time)".

Second, multiplication which is mentioned in the first narration was the product of two times, while in the second and third narration, multiplication was not mentioned, but just the addition of the amount of credits. It leads to one of two possibilities: (1) understanding each narrations on its own basis, so we can understand that "the forbidden riba is the addition 
of the amount of debt in certain circumstances, whether the additions are doubled or not doubled; (2) combining these narrations, so we can understand that addition is the narrations that did not mention that multiplication is the doubled addition. The second opinion is externally supported by the valid editorials.

In describing the narrations mentioned above, and other narrations, alTabari concluded that riba adh'afan mudha'afah is the extra of the amount of credit due to delay in payment, or what is called riba al-nasi'ah. According to al-Tabari, someone who practiced riba was called as murbin due to he or she multiplied his properties at the expense of the debtor sacrifice either directly or as a result of the extra of a suspension of payments. Al-Tabari's conclusion was supported by Muhammad Rashid Rida which according to him it was also the conclusion of Ibn Qayyim.

'Abdul Mun'in al-Namir, a member of the Council of Leading Scholars of Al-Azhar and Sheikh Al-Azhar representatives, concluded that: "Riba which is forbidden is depicted on a debtor who has a properties attended by the ones who need it, then he offered to her the additional amount of debt obligations in return for a year or a month delay payment, and in the end the question (the borrower) was forced to submit and accept the offer unwillingly. "It has been explained above that the word means adh'afan mudha'afah means doubled. While the narrations stated, some of them explained proliferation and some are simply additions. Now we go to ask again: What is it forbidden only the addition of the proliferation or any form of additions in certain circumstances?

What is certain is that the text of the ayah means "double". Those who hold on the text states that it is the prohibition requirements. It means that, if it is not double, it is not forbidden. While others argue that the text is not a requirement but an explanation of the form of riba that is often practiced during the fall of the ayahs of al-Quran. Thus, they said further, the extra even without doubling is forbidden. Thus, to resolve it, it needs special attention the last ayah concerning riba, in particular the key words contained therein. Because, even if the text adh'afan mudha'afah is a requirement, but at the end what determines the essence of the forbidden riba is the ayah in the third stage. Here the first used as the key is the word of Allah wa dzaru ma bagiya min al-riba. The question that arises is: Does the word al-riba in ma'rifah (definite) refers to riba adh'afan mudha'afah?

Rashid Rida in this case suggests three reasons to prove that the word al-riba in Surah al-Baqarah, refers to the word al-riba in mudha'afah adh'afan it. First, the linguistic rules, namely the rules of vocabulary repetition in ma'rifah. What is meant by Rashid Rida is the rule that states if there is a recurring ma'rifah, the definition of the second vocabulary (repeated) is the same as the first vocabulary. The word al-riba in Surah Al 'Imran, 3: 130 in the form of ma'rifah, as well as in Surah al-Baqarah, 2: 278. So this means that riba which is meant in the ayah of the last stages is the same as the riba in second stage which is in adh'afan mudha'afah. Second, the rules to understand the ayaha which are not conditional on the same ayah but 
Jurnal Ekonomi dan Perbankan Syariah

Vol. 5. No.1, April 2017: 5-18, ISSN (cet): 2355-1755 | ISSN (online): 2579-6437

| 13

conditional. The application of this rule to the ayahs of riba is to understand the meaning of the ayahs of al-Baqarah which are unconditional based on the word of al-riba which is conditional of adh'afan mudha'afah on Ali 'Imran. Thus, what is meant by al-riba in the ayahs of the last final stage is the doubled riba. Thirdly, observed by Rashid Rida that the al-Quran talks about riba always coupled or confronted with talk about sadakah, and riba is named as zhulm (persecution or oppression).

What is proposed by Rashid Rida above, about the meaning of riba meant by al-Quran in the ayahs of the final stage in al-Baqarah may still be rejected by some scholars - among others - by stating that the principle of language that is expressed it can not be applied except to the circuit arrangement of the editors, not the editors who apart as far as al-Baqarah with Ali 'Imran, as well as stating that the word adh'afan mudha'afah not a requirement but merely an explanation of the circumstances which are commonplace at the time, so that the second rule can not be applied. Nevertheless, Rashid Rida conclusion can be justified. This justification is based on the clear narrations and plenty of cause of nuzul of the ayahs of alBaqarah.

The conclusion of narrations includes:

1. Al-'Abbas (the Prophet's uncle) and someone from Bani alMughirah family cooperate to provide debt with riba to the people of the Thaqlf tribe. Then with the advent of Islam (and the Prohibition of riba) they still have (the debtor) the remaining many treasures, so it was revealed this ayah (Surah al-Baqarah, 2: 278) to prohibit them picking up the rest of their wealth in the form of riba which they practiced in Jahiliyah Era.

2. The ayah downs concerning on Thaqlf tribes which practice riba, then (they converted to Islam) and agree with the prophet not to do riba anymore. However, at the time of the opening of Makkah city, they still want to levy the rest of the money from their rba which have not been collected they did before the fall of the prohibition of riba, as if they thought that the prohibition has not apploed retroactively. Then the ayahs came to affirm the prohibition on the levy of riba. On the basis of these narrations and other narrations, Ibn Jarir stated that these ayahs mean: "Leave the demands of what remains of riba, i.e, the excess of your capital..." It was therefore it is the appropriate translation found in al-Quran and its translation, published by the Department of Religion, namely: "Leave the rest of riba that have not been collected."

On this basis, it is not appropriate to make the definition of riba in the last ayah down exceeds the definition of riba in Surah Al 'Imran (adh'afan mudha'afah). Because the questioned riba is the riba, which they conducted in the past (Jahiliyah). So in the end it can be concluded that riba forbidden by Qur'an is that he mentioned as adh'afan mudha'afah or that has been termed as riba al-nasiah. 
Back to the beginning. Does it mean that if the extra or excess is not "multiplied" in nature is not forbidden in al-Qur'an? The answer, here is in the next keyword, which is fa lakum ru'usu amwalikum (for you is your capitals) (Qur'an 2: 279). It means that what they are entitled to get back is only their capitals. If so, any extra or excess of the capital which is levied in the same condition with what happened in the fall of riba ayahs can not be justified. And thus this keyword specifies that any form of extra or excess of either doubled or not, has been forbidden by al-Qu'ran with the fall of the ayahs. And this means that the word adh'afan mudha'afah is not a requirement but merely an explanation of riba that is generally practiced.

Thus, this makes the issue of the words adh'afan mudha'afah do not matter anymore, because whether it is qualified or not, what is meant by multiplication or not, in the end what is forbidden is any form of excess. However, it needs to be underlined that the questioned advantages are in the same condition as it happened in the fall of al-Qur'an and signaled by the closing Surah al-Baqarah, 2: 279, namely la tazhlimun wa la tuzhlamun (you do not persecute and are not also persecuted).

From some narrations of the riba practice during the descent of alQur'an, as stated above, shows that such practices contain the persecution and oppression of the people who need it and who should get a help. It is confirmed by the closing Surah al-Baqarah, 2: 279 above, as before it was strengthened by the explanation of riba and alms, as stated by Rashid Rida, indicating that the needs of the borrower are such urgency and the situation is so severe, so naturally he or she was given with help of alms, not a loan, or at least given a loan without burying alms. Then in Surah al-Baqarah, 2: 280 confirmed that, and if the person who owes is in trouble (so are not able to pay at a set time), give him or her postponement until he or she ready, and you give alms (part or all of the debt) better for you, if you knew. The ayah above further strengthens the conclusion that the excess collected, especially in the form of multiplication, is persecution for the borrower.

From the above explanation, it can be underlined that riba during the fall of al-Qur'an is the excess collected together with the amount of debt that contain elements of persecution and oppression, not just excess or increase the amount of debts.

It is also reinforced by Rasulullah practice who pay the debts by exttra or more value. The companions of the Prophet, Abu Hurayrah, tells us that Rasulullah once borrowed a camel with a certain age to someone, then that person came to him and collect it. And when looking for the camel which looks appropriate in age as camel borrowed but the Rasulullah did not get one but older. Then he asked them to give the camel to the person who loaned it to him, he said, "Inna khayrakum ahsanukum qadhâ'an" (The best of you is the best who paid debts). Jabir, the Prophet's companions, also informed that he once gave loan to Rasulullah. And when he came to him, Rasulullah paid his debt and excess it. Hadith above and then narrated by Bukhari and Muslim. 
Jurnal Ekonomi dan Perbankan Syariah

Vol. 5. No.1, April 2017: 5-18, ISSN (cet): 2355-1755 | ISSN (online): 2579-6437 $1 \mathbf{1 5}$

It is true that there is also a narration which stated that kullu qardhin Jarra manfa'atan fahuwa Haram (each receivable that attract or generate benefits, it is prohibitted). But this hadith was rated by the scholars of Hadith as Hadith that can not be accounted for validity, so it can not be used as a legal basis. Thus, it is better to quote what was written by Shaykh Muhammad Rashid Rida in commentary of al-Manar, after explaining the meaning of riba meant by al-Qur'an: "It is not also included in the definition of riba, if someone gives to others treasure (money) to invest while setting him he results of operations in a certain level. Since the transaction is beneficial for managers and for property owners, while riba is forbidden to harm the one without a single sin (cause) except constraint, as well as the benefit of others without any effort except persecution. Thus, it is not possible the law provisions are equal in the sight of God's justice, nor later in the view of a reasonable or justly person. "

\subsection{THE IMPACT OF RIBA IN ECONOMY}

In financial transactions, exploitation and injustice may occur. In terms of savings, for example, Islam forbids to impose fines if the debt is paid lately because the principle of debt in this case is to help others (tabarru ') and it is not allowed to take advantage in tabarru'. In the riba of jahiliyah, exploitation potential is very high. In addition, the unilateral profit-taking in financial transactions, is also forbidden in Islam, known as riba nasi'ah, where there is an agreement to pay interest in the transaction of debt or financing. In this case, one party will get benefit for sure, while the other parties only enjoy the profits. Obviously this is not fair. Thus, the implementation of the use of riba can be bad for the economy, namely:

1. Inequality of income and wealth distribution. The principle of riba which gives fixed income on the one hand (financiers) and not fixed income on the opposing side (employers).

2. The potential for exploitation of the weaker party and gain more in favor of the rich. Riba system has the tendency of capital accumulation on the party which has high capital.

3. The allocation of economic resources is not efficient. Interest principle and system bring the trend of allocation of funds is not based on the prospect of business profitability but rather on the basis of repayment ability (Collectable) and the value of the collateral (collateral).

4. Inhibition of investment.

In addition, the impact of ribais not only influential in economic life, but in all aspects of life in the midst of society, namely:

1. Riba can lead to hostility between personals and reduces the spirit of cooperation / mutual help with our fellow human beings. By giving extra to the borrower will give rise to a feeling that the borrower 
does not know the trouble and do not want to know the troubles of others.

2. The growth of spender and lazy mental. By lending money at interest, the lender can get extra income from time to time. This situation leads to the assumption that in a limited period he get extra regular income, thereby reducing the dynamic, innovation and creativity in work.

3. Riba is one form of colonialism. Creditors who lend capital to demand the more payments to the borrower with the value that has been agreed. Making the creditor has ligetimated to perform actions that are not good for demanding the deal. Because in the creditor agreement it has calculated the gains obtained from excess of interest that will be earned, and it's actually just a hope and not yet materialized.

4. The rich get richer and the poor poorer. For people who earn more revenue will have an opportunity to raise revenue to lend loans to others. Meanwhile, for those who have a small income, are not only difficult to repay the debt but also must think the interest that will be paid.

5. Riba in fact is theft, because the money does not bring forth money. Money does not have a function other than as a means of exchange that have stable properties because the value of money and goods are the same or intrinsic. If money is deducted the money is not worth again, even its value is no more than a paper. Therefore, the money can not be used as a commodity.

6. High interest rates lower their interest to invest. The investors will take into account the amont of the borrower price or the bank interest rates. Investors do not want to bear the high cost of production resulted from interest costs by reducing production. When it happens it will reduce employment and income that would hamper the economic growth.

With the impact of riba, both on the economy and people's lives, the collective effort is required, planned and organized to reduce it and provide the better alternative. Therefore, the simultaneous and continuous measures are required in struggling the four things as following:

1. Educating the public and inviting their participation in the process of the abolition of riba system. System of democratic governance has great potential in inviting people to fight against injustice and exploitation of the riba system.

2. Reducing and eliminating the causes which make investors using the principle of interest. The investors will be reluctant to offer capital to entrepreneurs with the principle of sharing when the currency 
Jurnal Ekonomi dan Perbankan Syariah

Vol. 5. No.1, April 2017: 5-18, ISSN (cet): 2355-1755 | ISSN (online): 2579-6437

17

depreciation has always happened and little assurance that the employer would not deceive them.

3. Reducing and eliminating the causes of society and employers to have the system of interest (riba). During the depreciation occurred and could use the savings funds, and on the other bank offers interest on savings / deposits above the inflation rate, it is difficult to invite people to avoid saving their money in conventional banks. The best policy is to lower market interest rates and the rate of inflation so that people no longer expect that the time value of money is positive. Therefore, other standards are required for banks to compensate savers or depositors, as well as the need for a suitable incentive for borrowers with the principle of non-interest so that the chances of fraud can be avoided. This standard needs to be changed, so that the big capital will only be given to investments that really require big capital.

4. Preventing the decline in production and unemployment. The capitalist takes time to move from a system of interest to the sharing system, from risk shifting system to risk sharing system, because in this case they must take the business risk.

\section{CONCLUSION}

The need for the government to assist those efforts. The government policy very often sided and are dictated by the interests of capitalists and rulers. The democratic system of government cannot guarantee the loss of practice of exploitation of the weak and the culture of corruption / fraud. The role of economists in setting interest-free system will be meaningless when the culture of deception, exploitation still survive. Therefore the government should take legislative and administrative measures that support the implementation of non-interest system.

\section{REFERENCES}

Alma, Mukhtar dan Juni Priansa, Donni. (2009). Manajemen Bisnis Syari'ah. Bandung: Alfabeta.

Al-Maraghiy,Ahmad Mushthafa. (1946). Tafsir Al-Maraghiy, Mesir: Mushthafa al-Babi Al-Halabiy, jilid III.

Al-Nandr, Abdul Mun'im. (1986). Al-Ijtihad, Kairo: Dar al-Syuruq.

Al-Qurthubiy, Muhammad bin Ahmad al-Anshariy. (1967). Al-Jami' li Ahkam Al-Qur'an, Kairo: Dar al-Kutub, jilid XIV.

Al-Shabuniy, Muhammad 'Ali. (1971). Tafsir Ayat Al-Ahkam. Beirut: Dar AlQalam, jilid I. 
Al-Shan'aniy, Muhammad bin Isma'il Al-Kahlaniy. (1950). Subul Al-Salam, Mesir: Mushthafa al-Babi al-Halabiy, Jilid III.

Al-Suyuthy, Jalaluddin. (1318h). Al-Itqan fi 'Ulum Al-Qur'an. Mesir: AlAzhar, Jilid I.

Al-Syawkaniy, Muhammad bin 'Ali. (1952). Nayl Al-Authar, Mesir: Mushthafa al-Babi al-Halabiy, Jilid V.

Al-Thabariy, Muhammad Ibn Jarir. (1954). Jami' al-Bayan fi Tafsir AlQur'an, Mesir: Isa al-Babi al-Halabiy, Jilid IV.

Al-Zanjany, Abdullah. (1969). Tarikh Al-Qur'an, Beirut: Al-'Alamiy.

Al-Zarkasyiy, Badruddin. (1957). Al-Burhan fi 'Ulum Al-Qur'an, Tahqiq Muhammad Abu Al-Fadhil. Mesir: Isa al-Babi al-Halabiy, jilid I.

Dahlan, Abdul Aziz. (2000). Ensiklopedi Hukum Islam. Jakarta: PT. Ichtiar Baru van Hoeve.

Suwiknyo, Dwi. (2010). Kompilasi Tafsir; Ayat-Ayat Ekonomi Islam, Yogyakarta: Pustaka Pelajar.

Sudarsono, Heri. (2003). Bank dan Lembaga Keuangan Syari'ah Deskripsi dan Ilustrasi. Yogyakarta: Ekonesia.

Katsir, Ibn. (tth). Tafsir Al-Quran Al-Azhim, Singapura: Sulaiman Mar'iy, jilid III.

Khamid, Nur. (2010). Jejak Langkah Sejarah Pemikiran Ekonomi Islam, Yogyakarta: Pustaka Pelajar.

Muhammad bin Abdillah (Ibn al-'Arabiy), Abu Bakar. (1957). Ahkam AlQur'an, tahqiq Muhammad Ali Al-Bajawi. Mesir: 'Isa al-Babi AlHalabiy, Jilid III.

Rasyid Ridha, Muhammad. (1376H). Tafsir al-Manar. Mesir: Dar Al-Manar, jilid III. 